ISSN: 2224-0616

Int. J . Agril. Res. Innov. \& Tech. 4 (1): 16-23, J une, 2014

Available online at http:// www.jjarit.webs.com

\title{
COMMUNITY PERCEPTIONS TOWARDS THE ESTABLISHMENT OF AN URBAN FOREST PLANTATION: A CASE OF DZIVARESEKWA, ZIMBABWE
}

\author{
A. Mureva, T. Nyamugure*, C. Masona, S.M. Mudyiwa, P. Makumbe, \\ M. Muringayi and G. Nyamadzawo
}

Received 6 November 2013, Revised 13 May 2014, Accepted 28 June 2014, Published online 30 June 2014

\begin{abstract}
The health of urban forest communities not only depend on the government and nongovernmental organizations, but also strongly rely on local community stewardship. A study was carried out to assess community perceptions on the establishment of an urban forest plantation among urban residents in Dzivaresekwa, an urban area in Harare. Randomized systematic sampling was used to select 150 households and one resident per household was interviewed using a pretested questionnaire with both closed and open-ended questions. The objectives of the study were to determine how age and gender and employment status variables, were related to the urban residents' perceptions towards establishment of a forest plantation in an urban area. Most females (58.3\%) viewed the plantation as a threat while most men (51.7\%) viewed the plantation as a recreational area. The highest proportion (61.9\%) of the middle age group (21-40 years) perceived the plantation as a source of employment. There was a statistically significant relationship $(p=0.040)$ between gender and the general perception of establishing a forest plantation in the urban area. However, there was no statistically significant relationship $(\mathrm{p}=0.203)$ between age groups and the perception of establishing a forest plantation in the urban area. It is concluded that the community had diverse perceptions on urban community forestry.
\end{abstract}

Keywords: Community Perception, Urban Forestry, Plantation

Department of Environmental Science, Faculty of Agriculture and Environmental Science, Bindura University of Science Education, P. Bag 1020, Bindura, Zimbabwe

*Corresponding author's email: vamugure@gmail.com (T. Nyamugure)

\section{Introduction}

Urban and community forests play an instrumental role in the social, economic, and environmental well-being of urban residents. Trees provide a wide variety of goods and services and are one of the most important forms of vegetation in an urban environment (Lorenzo et al., 2000). Trees reduces air pollution through carbon sequestration, they enhance air quality, moderate microclimate, reduce noise level and provide a habitat for wildlife (Fraser and Kenney, 2000; Lorenzo et al., 2000). Urban trees and forests in the developing world also provide firewood for energy, timber for use in construction activities, fruits, medicines and other useful minor forest products. Wood is still the main source of energy for cooking and heating, because alternative sources, when available, are unaffordable to the majority of urban residents. Despite their importance, Zimbabwe's urban trees, woodlands and forest resources are under increasing threat from the rapid increase of urban agriculture, expansion of urbanization and the high demand of fuel wood due to prolonged electricity shortage. The loss of trees within urban areas has led to long distance marketing of firewood. This has resulted in a number of rural lands surrounding the urban centers of Harare, Chitungwiza, Bulawayo and Gweru losing vast lands of trees for firewood. (Makonese and Mushamba, 2004). Strong and responsive programs similar to other community projects in infrastructure development are required to protect urban trees and forests. In urban environments, healthy community forests require ongoing stewardship as well as cooperation at governmental, organizational, and community levels.

In the process of designing, planning, and managing urban fringe forests it is important to consider urban people's opinions regarding establishment or presence of these forests. Local resident participation in the planning, planting, and management stages of forest care is essential to urban forest sustainability. A failure to address people's requirements may generate conflicts between users, planners, and managers, as has happened historically in relation to urban forests (Konijnendijk, 2000). To encourage participation in community forestry, positive attitudes of the 
public towards trees and education about the benefits they provide is essential. To determine the potential for resident stewardship of urban trees in Dzivaresekwa community and the need for educational programs in the future, the study sought to gather information on residents' knowledge and perceptions of urban trees and forests.

\section{Materials and Methods}

\section{Study area}

The woodland is located in Harare, Dzivaresekwa, a high-density residential area in Zimbabwe and its coordinates are, latitude $17.8065^{\circ} \mathrm{S}$; longitude $30.925^{\circ} \mathrm{E}$, (Fig. 1). The study area has approximately 1500 housing units and approximately a population of 10,100 people. The area is characterized by annual precipitation between 725-974 $\mathrm{mm} /$ year and average maximum temperature 15.5 to $20^{\circ} \mathrm{C}$ (FAO, 2012).The woodland is in an area made up of the miombo and open savanna grassland. In the open grassland, there are perennial grasses that include thatching grass (Hyparrhenia filipendula), spear grass (Heteropogon contortus), and couch grass (Cynodon dactylon). Bushes and shrubs are abundant in the forest zone with sandy loam and gravel soil supporting a wide variety of trees with Brachystegia spiciformis and Jubernadia globiflora dominating.

\section{Data collection}

A sampling intensity of $10 \%$ was used and households were sampled using a randomized systematic sampling to come up with 150 households. The first house was randomly selected and thereafter data was collected from every $10^{\text {th }}$ house in the sampling frame. The respondents provided information on their homes' possible distance from the plantation area choosing from the groups $(<150 \mathrm{~m}, 150-300 \mathrm{~m}$, and $>300 \mathrm{~m}$ radius).

The household survey was carried out using a pretested questionnaire with both closed and open-ended questions to examine the level and forms of participation of local people on the establishment of an urban plantation. The information collected during the study included the perceived impacts of establishing the urban plantation on the livelihood of people in Dzivaresekwa and residents' perceptions on the urban plantation. Two focus group discussions disaggregated by sex were conducted with residents in the area, and key informant interviews were held with two representatives from the Dzivaresekwa District office, a representative of urban farmers, the plantation supervisor, the District Councilor and a representative from the Dzikwa Trust Directors.

\section{Analysis of data}

Data were analysed using Statistical Package for Social Sciences (SPSS) version 21. To analyse the perception of residents on social, economic and environmental benefits towards plantation a multinomial regression model was used. Social, economic or environmental benefits were taken to be the dependent variable while age, gender, work status, distance from plantation and knowledge of plantation were taken to be the explanatory variables. A binary logistic model was used to test the involvement of residents in plantation activities and whether they derived any benefits from planting trees. In both cases the dependent variable was a yes or no response. Age, gender, work status, distance from plantation and knowledge of plantation were taken to be the explanatory variables. In fitting the model to the data, all explanatory variables were included in the model. These were subsequently removed if they did not significantly contributed to the model. Removal of terms was stopped when a Minimal Adequate Model (MAM) was obtained. All tests were performed at $5 \%$ level of significance

\section{Results}

\section{Demographic information of respondents}

A total of 150 residents were interviewed. The respondents constituted of $60.7 \%$ females and $39.3 \%$ males. Most of the respondents (45.3\%) were in the 21-40 years age group followed by the 41-60 years (26\%), the 61 +years ( $18.7 \%)$, and the group with the least number of respondents was the $15-20$ years ( $10 \%)$.

Perceived socio-economic and environmental values of the plantation on peoples' livelihoods.

\section{Social benefits and threats}

Nagelkerke pseudo $r$-square $=0.71$ which means that $71 \%$ of the variation is explained by the model.

Contribution of each parameter to the model:

Perception of residents on social benefits and threats towards plantation significantly differed based on distance from plantation $\left(\chi^{2}=50 ; \mathrm{df}=10\right.$; $\mathrm{P}<0.001)$, age $\left(\chi^{2}=82.8 ; \mathrm{df}=15 ; \mathrm{P}<0.001\right)$, gender $\left(\chi^{2}=12.7 ; \quad \mathrm{df}=5 ; \quad \mathrm{P}<0.027\right)$ and work status $\left(X^{2}=72.1 ; \mathrm{df}=10 ; \mathrm{P}<0.001\right)$. 


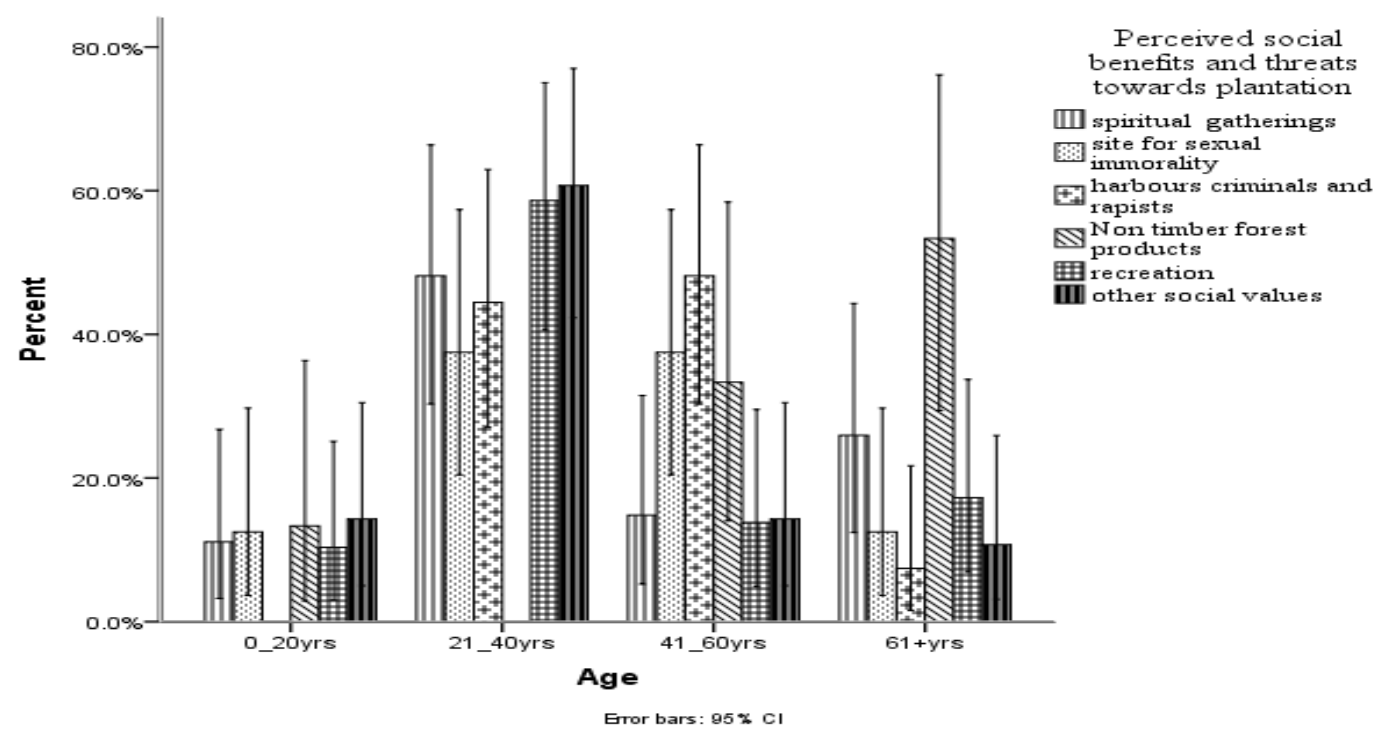

Fig. 1. Perceived social benefits and threats in relation to age

Older age (41 to 60 years and 61+ years) groups perceived plantations to be important for spiritual gatherings than young ( $0-20$ years) and middle age (21-40 years) groups ( $\mathrm{P}<0.005)$ (Fig. 1 and Table 1). The employed viewed the plantation to be a significantly important site for spiritual gatherings than the self- employed $(\mathrm{P}=0.002)$. Only the unemployed significantly perceive that

Table1. Perceived social benefits and threats

\begin{tabular}{lllccc}
\hline Category & Parameter & Level & $\begin{array}{c}\text { Relative odds } \\
\text { (coefficients) }\end{array}$ & Wald Chi sq. & P-value \\
& & $12-20$ years & -2.8 & 4.81 & 0.028 \\
\multirow{2}{*}{ Spiritual gatherings } & Age & $21-40$ years & -3.4 & 8.77 & 0.003 \\
& Work status & Employed & 3.0 & 9.44 & 0.002 \\
\hline Sitefor sexual immorality & Workstatus & Unemployed & 2.8 & 7.43 & 0.006 \\
\hline \multirow{4}{*}{ Harbours criminals } & Age & $21-40$ years & -4.9 & 8.25 & 0.004 \\
& Gender & Male & -2.6 & 4.35 & 0.037 \\
\cline { 2 - 6 } & \multirow{2}{*}{ Distance from plantation } & $150 \mathrm{~m}$ & -2.5 & 8.73 & 0.003 \\
& & $300 \mathrm{~m}$ & -4.2 & 10 & 0.004 \\
\cline { 2 - 6 } & Workstatus & Employed & 6.1 & 15.03 & $<0.001$ \\
\hline \multirow{2}{*}{ NTFPs } & Workstatus & Unemployed & 3.5 & 9.65 & 0.002 \\
& Age & $0-20$ years & -3.0 & 5.15 & 0.023 \\
\hline Recreation & Workstatus & Employed & 3.1 & 8.17 & 0.004 \\
\hline
\end{tabular}

The dependant variable, "other social benefits" was used as the reference category. For the explanatory variables: age group "61+", gender "female", distance " $450+\mathrm{m}$ " and work status "self-employed" were used as the reference categories. Parameters with significant negative coefficients decrease the likelihood of that response category with respect to the reference category while parameters with significant positive coefficients increase the likelihood of that response category with respect to the reference category. plantations are sites for sexual immorality $(\mathrm{P}=0.006)$. Males, middle aged people, and those staying at $150 \mathrm{~m}$ and $300 \mathrm{~m}$ from the plantation do not think that forests are places that significantly harbour criminals $(\mathrm{P}<0.05)$ while only the employed thought that plantations harbour criminals $(\mathrm{P}<0.001)$ [Table 1].

\section{Perceived economic value}

Nagelkerke pseudo $r$-square $=0.62$ which means that $62 \%$ of the variation was explained by the model.

Perception of residents on economic benefits from plantations significantly differed based on age $\quad\left(\chi^{2}=193.7 ; \quad d f=9 ; \quad P<0.001\right), \quad$ gender $\left(\chi^{2}=174.98 ; \quad \mathrm{df}=3 ; \quad \mathrm{P}<0.001\right), \quad$ work $\quad$ status $\left(\chi^{2}=157.4 ; \quad d f=6 ; P=0.016\right)$ and knowledge of forest plantation $\left(\mathrm{X}^{2}=163.1 ; \mathrm{df}=3 ; \mathrm{P}<0.001\right)$. 

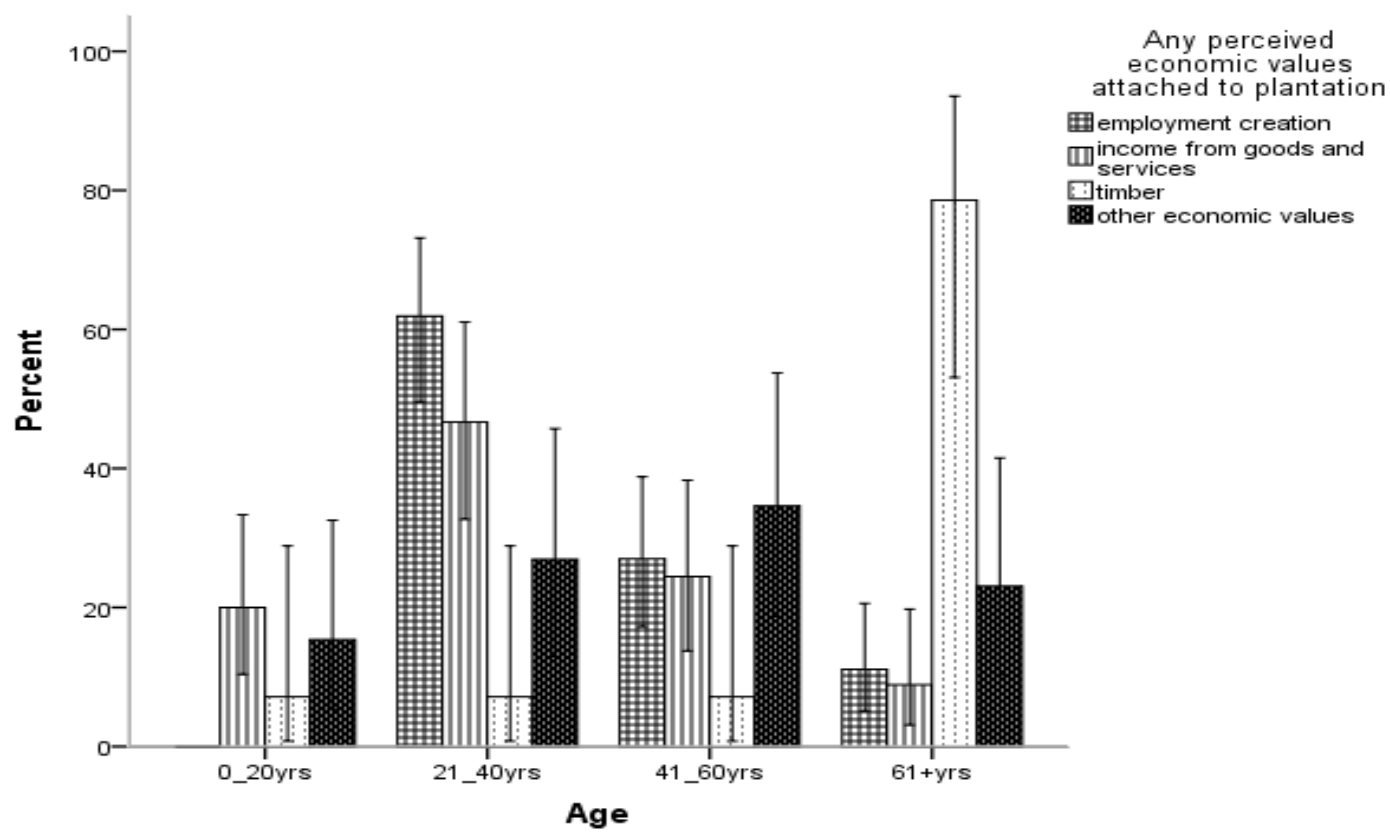

Eror bars: $95 \% \mathrm{cl}$

Fig. 2. Perceived economic values in relation to age

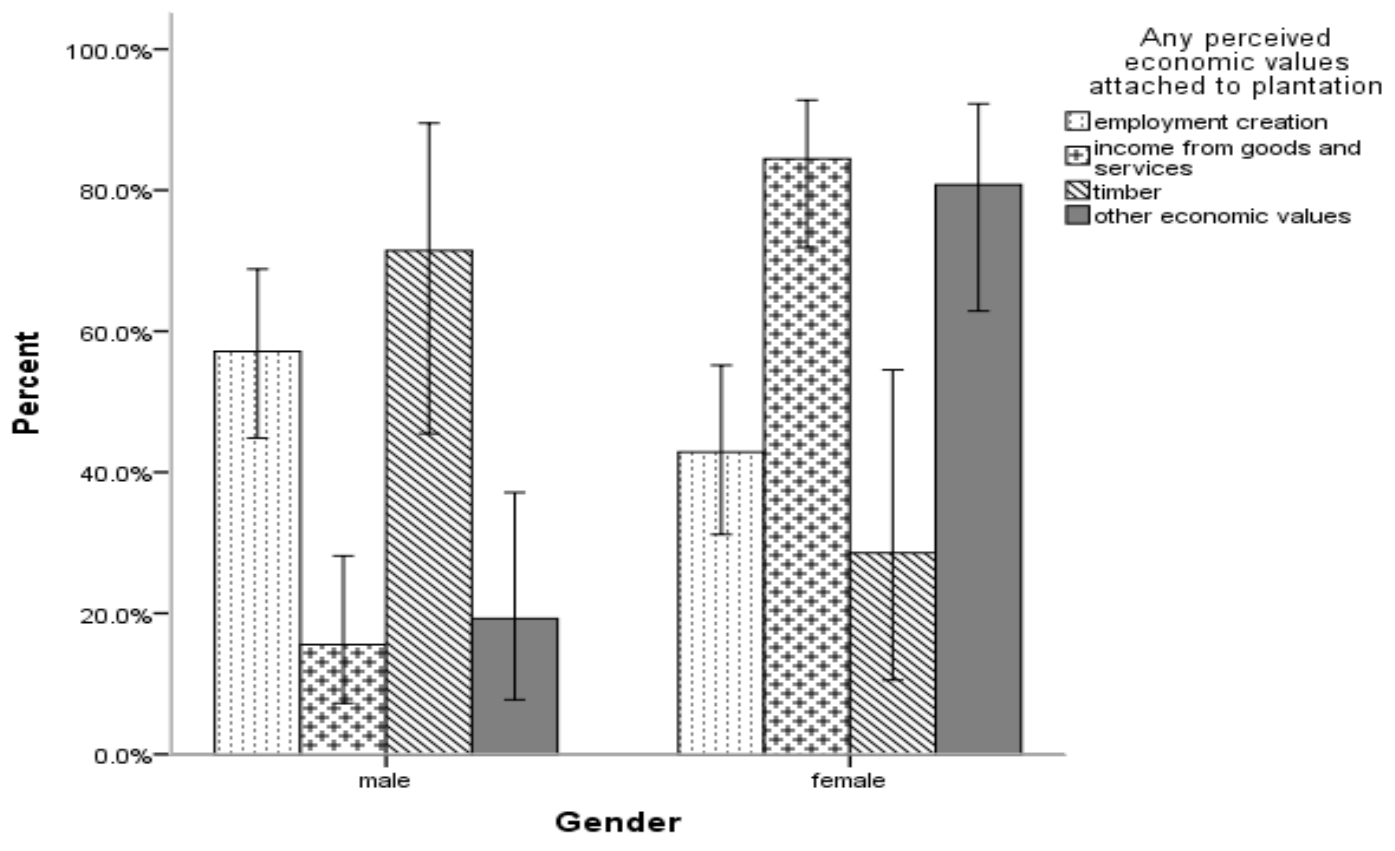

Eror bars: $95 \% \mathrm{Cl}$

Fig. 3. Perceived economic values in relation to gender

Further investigation showed that males and age plantations ( $\mathrm{P}=0.004)$ (Fig. 6 and Table 2). group 21-40 years perceive that the forest Residents with knowledge of the plantation and plantation significantly provides employment those who were young (12-20 years old) perceived $(\mathrm{P}<0.005)$ (Fig. 2 and Table 2). In addition males that forests are sources of income $(\mathrm{P}<0.02)$ perceive that timber is a major benefit of the [Table 2]. 
Table 2. Perceived economic values of the plantation

\begin{tabular}{llllll}
\hline Category & Parameter & Level & Relative odds & Waldi Chi sq. P-value \\
\hline \multirow{2}{*}{ Employment benefits } & Age & $21-40$ years & 3.1 & 8.02 & 0.005 \\
& Gender & male & 2.8 & 11.8 & 0.001 \\
\hline \multirow{2}{*}{ Income from goods } & Age & $12-20$ years & 3.3 & 5.68 & 0.017 \\
Timber & Knowledge of plantation & Yes & 3.4 & 9.08 & 0.003 \\
& Gender & male & 3.0 & 8.29 & 0.004 \\
\hline
\end{tabular}

The dependant variable, "other economic benefits" was used as the reference category. For the explanatory variables: age group "61+", gender "female" and knowledge of plantation "yes" were used as the reference categories. Parameters with significant positive coefficients increase the likelihood of that response category with respect to the reference category.
Perceived environmental value

Nagelkerke pseudo r-square $=0.46$

Perception of residents on environmental benefits from plantations significantly differed based on the following parameters: age $\left(\chi^{2}=90.3 ; 3=\mathrm{df}\right.$; $\mathrm{P}<0.001)$, work status $\left(\mathrm{X}^{2}=74.98 ; 2=\mathrm{df} ; \mathrm{P}=0.007\right)$ and knowledge of forest plantation $\left(\chi^{2}=91.2\right.$; $1=d f ; P<0.001)$.

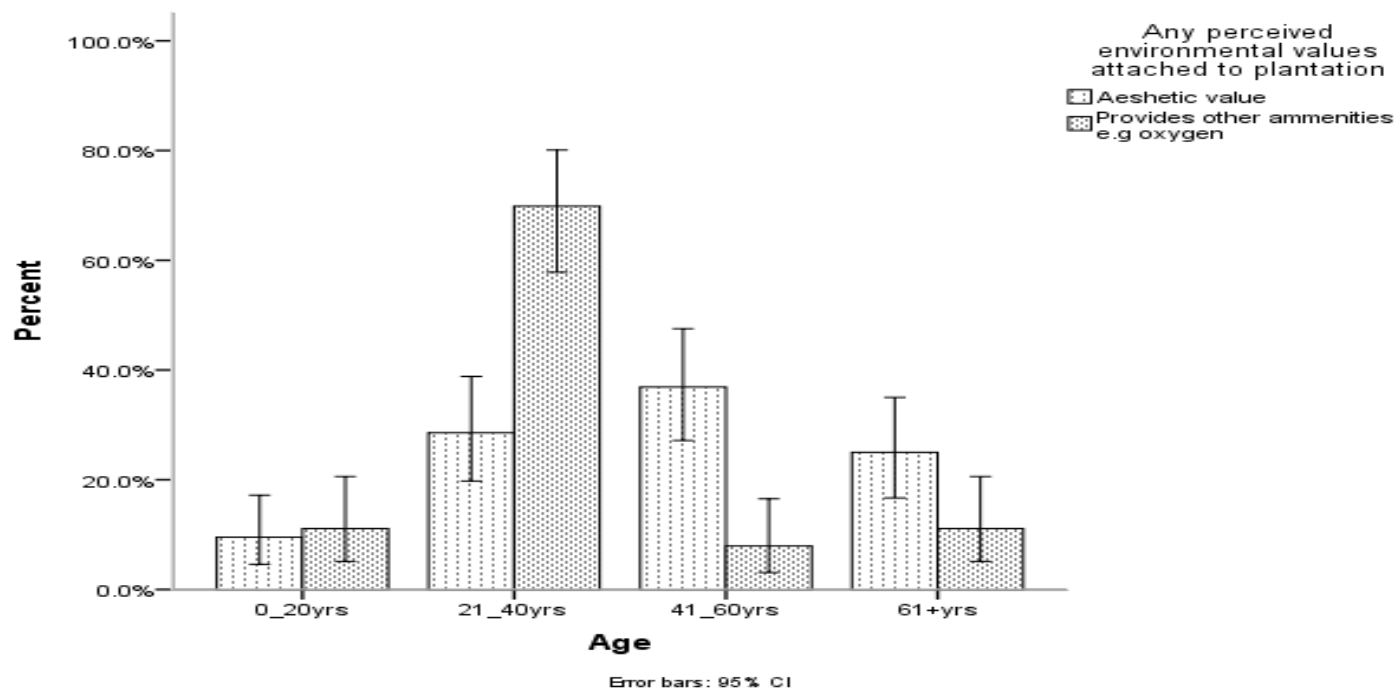

Fig. 4. Perceived environmental values in relation to age

More females appreciated the plantation as a slightly differed with males in appreciation for its provider of other amenities like clean air and aesthetic values (51.2\%) (Fig. 5).

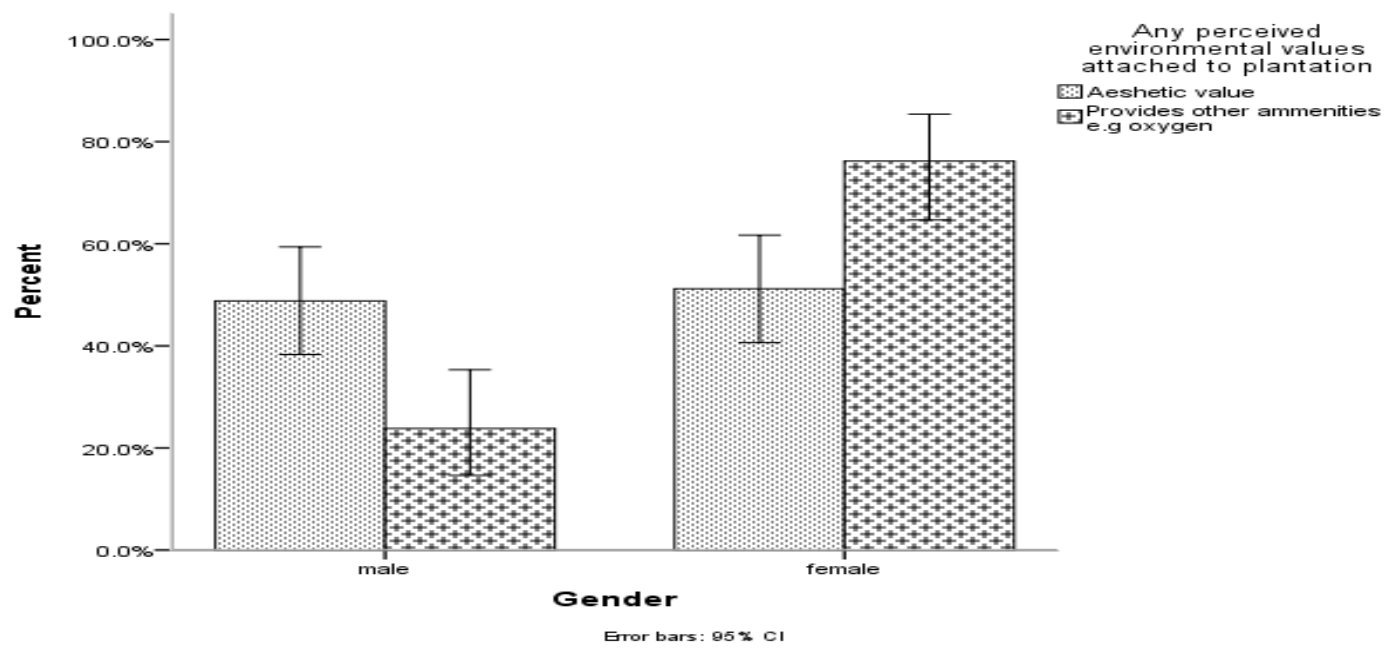

Fig. 5. Perceived environmental values in relation to gender 
People aged between 21-40 years, the unemployed and those who have knowledge on plantations are about twice significantly less likely to perceive the plantations as source of aesthetic value than $64+$ age group, the selfemployed and those who have no knowledge of plantation $(\mathrm{P}=0.05)$ [Table 3].

Table 3. Perceived environmental values

\begin{tabular}{|c|c|c|c|c|c|}
\hline Category & Parameter & Level & Relative odds & Waldi Chi sq & P-value \\
\hline \multirow{3}{*}{ Aesthetic value } & Age & $21-40$ years & -1.8 & 6.5 & 0.011 \\
\hline & Work status & Unemployed & -1.9 & 9.09 & 0.003 \\
\hline & Knowledge of plantation & Yes & -2.4 & 21.1 & $<0.001$ \\
\hline
\end{tabular}

For the dependant variable, "other environmental amenities" was used as the reference category. For the explanatory variables: age group " $61+$ ", work status "unemployed" and knowledge of plantation "yes" were used as the reference categories. Parameters with significant negative coefficients decrease the likelihood of that response category with respect to the reference category

\section{Willingness to be part of the reforestation project}

Involvement in plantation activities $(\mathrm{y} / \mathrm{n})$ using binary logistic model
Work status and distance from plantation were the two parameters that influenced significantly the involvement of residents in plantation activities [work status: Wald Chi-square $=8.24$; $2=d f ; P=0.016$. Distance from plantation: Wald Chi-square=19.16; $2=d f ; P<0.001]$.

Odds of being involved in plantation activities is significantly higher when the respondent was employed (0.93x) and unemployed (1.5x) than self-employed $(\mathrm{P}<0.05)$. People living closer to the plantation $(150 \mathrm{~m})$ are significantly less likely (2 times) to be involved in forest activities than people living far away $(\mathrm{P}<0.001)$ [Table 4].

Table 4. Willingness to be part of the reforestation project

\begin{tabular}{lllll}
\hline Parameter & Level & Relative odds & Wald Chi square & P-value \\
\hline \multirow{2}{*}{ Work status } & Employed & 0.93 & 4.45 & 0.035 \\
& Unemployed & 1.5 & 7.42 & 0.006 \\
\hline Distance from plantation & $150 \mathrm{~m}$ & -2.0 & 16.19 & $<0.001$ \\
\hline
\end{tabular}

The dependant variable, "yes" was used as the reference category. For the explanatory variables: work status "unemployed" and distance from plantation " $450+m$ " were used as the reference categories. Parameters with significant negative coefficients decrease the likelihood of that response category with respect to the reference category while. Parameters with significant positive coefficients increase the likelihood of that response category with respect to the reference category

\section{Benefits of planting trees}

Perception on whether planting trees was beneficial than other activities was significantly affected by knowledge of forest plantation (Wald Chi square=4.1; $1=d f ; \mathrm{P}=0.043$ ) with those having knowledge of plantation having odds of $0.87 \mathrm{x}$ than those with no knowledge of plantation (Wald Chi-square=4.08; $\mathrm{P}=0.04$ )

\section{Discussion}

\section{Residents' perceptions towards establishment of an urban plantation}

The Dzivaresekwa people's perceptions were overall positive towards urban forestry possibly because the area is being used as a dumpsite posing health hazards to the community as compared to a forestry project, which comes as a development to the community.

Relationship of gender and age on the perceptions of establishing an urban forest plantation in Dziva resekwa

Gender had no relationship with urban resident's perceptions of establishing a forest plantation in Dzivaresekwa. Age group differences were found to produce possible divergences in perceptions.

Age has also been a contributory factor in perceptions as stipulated by Burgess (1995); elderly people's attitudes towards urban woodland have been addressed in previous studies these have tended to concentrate on negative perceptions. The use of green space varies hugely between different social groups with underrepresented user groups including the elderly, young people, women, ethnic minorities, disabled people and the economically disadvantaged (Fairburn et al., 2005). The differences in perceptions according to age group might be as because of the generation gap. Cohen et al. (2007) strongly suggests that the proximity of (peri-) urban forests and parks to where people live has a huge impact on levels of usage and therefore the benefits that can be gained from use. 
The 21-40yr age group had most respondents because it is the most active group of a society and given the high unemployment rate in Zimbabwe as a whole, the respondents in the age group were mostly found at home. The 61+ age group had few respondents because it is most likely that most of them had retired and gone to rural areas.

\section{Perceived socio-economic and environmental values on the livelihoods of people in Dzivaresekwa}

According to Meza (1992), urban forestry presents many social issues that require addressing to allow urban forestry to be seen by many as an advantage rather than a curse on their environment. Females were found to be concerned about the plantation being a site for sexual immorality and its potential to harbour criminals and rapists. Burgess (1995) indicated that people are afraid of becoming the victims of physical or sexual assault, robbery or bullying and intimidation from groups of young people in the woodland. In addition, a study carried out by Konijnendijk's (1999) showed that the concern about aspects of safety was widespread. In correlation with this study, urban forests in the Dutch cities of Haarlem and Amsterdam indicated that people do not always feel safe in urban forests. The same research also pointed out that some forests in France have gained a rather bad reputation due to safety problems. Lack of safety could mean threat by criminal elements and falling tree limbs. People generally as well as in the South Wales study were concerned by problems with urban forest abuse, such as the dumping of garbage, prostitution, homosexual activity and other ('semi') criminal or illegal activities, littering, dogs walking off their leash, illegal motorized traffic through the forest crossing, illegal fires and poaching, among others. Dzivaresekwa also has a record of high crime rates hence the varying responses both threats and benefits.

The research proved that in Dzivaresekwa females appreciated the plantation as a place with a high aesthetic value and providing other amenities. Habitat surveys, as well as studies focusing on flora and fauna, have all demonstrated the importance of tree cover for biodiversity in urban areas (Tyrvainen et al., 2005) and enhanced biodiversity. Urban plantations can often also enhance an area's recreational and aesthetic qualities (Chen and $\mathrm{J} \mathrm{im,} \mathrm{2008).This} \mathrm{research} \mathrm{has} \mathrm{proved} \mathrm{that} \mathrm{people}$ are not only biased towards monetary benefits but are able to appreciate nature. Dzivaresekwa often has sewage bursts all over but the plantation can help in air purification and sewer effluent absorption.

\section{Willingness to be part of the plantation project}

The reasons for willingness seemed to be more economically biased and those whose who did not show interest in the project were mainly the ones who owned small pieces of land in the plantation area.

\section{Conclusion}

The residents of Dzivaresekwa had diverse perception towards establishment of a forest plantation in their suburb though most of them had a positive perception towards urban forestry. Gender had no significant influence on perceptions of establishing a forest plantation in Dzivaresekwa. Age group differences produce possible divergences in perceptions. After an indepth assessment into the socio-economic and environmental values, the results indicated that people had perceived various benefits and threats.

\section{Recommendations}

Demographic information should be considered in community projects because the research clearly shows that age group differences had an effect on the people's perceptions in Dzivaresekwa. Though the people's perceptions were overall positive we do not have to ignore that there were also negatives so we have to try and conscientise them and make them realize the positivity of the forest plantation. Consideration of other factors such as education level and work status need to be considered in future projects.

To forage ahead with community forestry programmes and their implementation foresters should develop a two-way communication system with the residents. They should be involved in problem definition, the design of possible solutions, and evaluation of the proposed technological solutions. Women should be involved in community forestry programmes as decision makers and implementers as the wood collection and consumption is their responsibility, and they remain in the villages all year round. Women play a vital role in tree planting programmes as they show interest, positive attitude, and willingness to participate.

\section{References}

Burgess, J. 1995. Growing in ConfidenceUnderstanding People's Perceptions of Urban Fringe Woodlands. Countryside Commission, Cheltenham.

Chen, W.Y. and Jim, C.Y. 2008. Assessment and Valuation of the Ecosystem Services Provided by Urban Forests. In: M.M. Carreiro, Y.C. Song and J. Wu (Eds.) Ecology, Planning, and Management of 
Urban Forests. Springer, New York: pp. 5383.

Cohen, D.A., McKenzie, T.L., Sehgal, A, Williamson, S., Golinelli, D. and Lurie, N. 2007. Contribution of Public Parks to Physical Activity. American J. Public Health 97 (3): 509-514.

Fairburn, J., Walker, G. and Smith, G. 2005. Investigating Environmental Justice in Scotland - Links Between Measures of Environmental Quality and Social Deprivation Report UE4 (03)01, Scottish and Northern Ireland Forum for Environmental Research, Edinburghh.

FAO. 2012. country profiles. http:www.fao.org/countryprofiles/maps.aspi so3=ZWE\&lang=en

Fraser, E.D.G. and Kenney, W.A. 2000. Cultural background and landscape history as factors affecting perceptions of the urban forest. J. Arboric. 26 (2): 106-113

Konijnendijk, C.C. 1999. Urban forestry: comparative analysis of policies and concepts in Europe. Contemporary Urban Forestry Policy-Making in Selected Cities and Countries of Europe. Working Paper 20. European Forest Institute, J oensuu, Finland. pp. 266-289.

Konijnendijk, C.C. 2000. Adapting forestry to urban demands - role of communication in urban forestry in Europe. Landscape and Urban Planning: pp. 89-100.

Lorenzo, A., Blanche, C., Qi, Y. and Guidry, M. 2000. Assessing residents' willingness to pay to preserve thecommunity urban forest: A small-city case study. J . Arboric. 30 (1): 2835.

Makonese, M. and Mushamba, S. 2004. The Policy, Legislative and Institutional Framework for Urban Forestry in Zimbabwe, 34 UA-Magazine: pp. 34-35.

Meza, H.M.B. 1992. Current Situation of the Urban Forest in Mexico City. J. Arboric. 18: 33-36.

Tyrvainen, L., Pauleit, S., Seeland, K. and de Vries, S. 2005 Benefits and Uses of Urban Forests and Trees. In: C.C. Konijnendijk, Nilsson, K., Randrup, T.B. and Schipperijn (Eds.) Urban Forests and Trees. Springer, Berlin/Hieldelberg/New York: pp. 81-144. 